\title{
Editorial for Special Issue "Energy Dissipation and Vibration Control: Materials, Modeling, Algorithm, and Devices"
}

\author{
Gangbing Song $1, * \mathbb{C}$, Hong-Nan $\mathrm{Li}^{2}$ and Steve C.S. Cai ${ }^{3}$ \\ 1 Department of Mechanical Engineering, University of Houston, Houston, TX 77204, USA \\ 2 School of Civil Engineering, Faculty of Infrastructural Engineering, Dalian University of Technology, \\ Dalian 116023, China; hnli@dlut.edu.cn \\ 3 Department of Civil and Environmental Engineering, Louisiana State University, Baton Rouge, LA 70803, \\ USA; cscai@lsu.edu \\ * Correspondence: gsong@uh.edu
}

Received: 30 December 2019; Accepted: 31 December 2019; Published: 13 January 2020

check for updates

\begin{abstract}
Many engineering systems, from subsea pipelines to space structures, from moving vehicles to stationary skyscrapers, are subject to unwanted vibration excitations. Often vibration control can be considered as a problem of energy dissipation and vibration damping. The aims of this issue are to accumulate, disseminate, and promote new knowledge about vibration control, especially for topics related to energy dissipation methods for vibration damping. Topics in this issue reflect the start-of-the-arts in the field of vibration control, such as inerter dampers and pounding tuned mass dampers (PTMDs). This special issue also reports other types of new energy dissipation devices, including a multi-unit particle damper, a nonlinear eddy current damper, and layered dampers. Also reported in this issue are structural elements with innovative designs to dissipate energy. In addition, this special issue also reports two research studies on the dynamic responses of a structural foundation and an earth-retaining structure. Though most papers in this special issue are related to passive methods, one paper reports a semi-active vibration control via magnetorheological dampers (MRDs), and another two papers report active vibration controls using piezoelectric transducers and inertial actuators, respectively.
\end{abstract}

Keywords: vibration control; energy dissipation; passive vibration control; tuned mass damper; pounding tuned mass damper; viscoelastic materials

Many engineering systems, from subsea pipelines [1,2] to space structures [3,4], from moving vehicles [5] to stationary skyscrapers [6], are subject to vibration excitations. Problems related to vibrations are ubiquitous, from the fatigue caused by many low-amplitude vibration excitations $[7,8]$ to the structural failure of buildings caused by excessive seismic events $[9,10]$. In addition, many civil structures are exposed to the environment and are subjected to many adverse effects such as thermal cycling [11] and corrosion [12], resulting in damages such as cracks [13] and reduced structural stiffness [14]. In these situations, vibration damping becomes even more important. The study of vibrations and the control of vibrations has been a fundamental cornerstone of engineering. The breadth of vibration engineering is matched by the depth of field. Numerous methods, including active [15,16], passive [17,18], semi-active [19,20], and hybrid [21] methods, have been proposed, and a wide range of devices have been developed to control vibrations.

Many vibration control problems can be considered as a problem of energy dissipation and vibration damping $[18,19]$. The problem encompasses multiple interdependent aspects of research and engineering, including the invention of new energy dissipation materials, the establishment of new 
mathematical models [22], the development and implementation of new control algorithms, and the design of novel damping devices $[23,24]$. Discoveries made in one aspect can lead to breakthroughs in others.

The aims of this issue are to accumulate, disseminate, and promote new knowledge about vibration control, especially for topics related to energy dissipation methods for vibration damping. Topics in this issue reflect the start-of-the-arts in the field of vibration control. In recent years, new dampers employing inerters have received much attention. In this special issue, both modeling and applications related to inerter dampers are addressed. On the modeling side, new equivalent linearization methods for a control system with a clutching inerter damper are developed [25], and on the application side, the inerter dampers are applied to the vibration control of suspended structures [26] and cables [27]. The inerter dampers are effective in reducing structural vibrations.

Recent years have seen the increasing research in pounding tuned mass damper (PTMD) that has advantages of being simple to use, easy to maintain, robust to the target structural frequency, and having a high energy dissipation capacity [28-30]. In this issue, a new type of PTMD that uses a shape memory alloy sponge as the energy dissipating material is reported [31], and the application of the PTMD is extended to the vibration control of suspended piping systems in buildings [32]. Since viscoelastic materials are used in the conventional PTMDs [17,18,24] and the effectiveness of viscoelastic materials are negatively impacted by the water depth (pressure), for its underwater applications, conventional PTMD can only be applied in shallow water where the pressure is low. With the metallic porous shape memory alloy sponge whose damping performance is not impacted by water depth, the application of PTMD can be extended to deep water. In the past, there is no study on the impact of seawater on viscoelastic materials' damping effect. In this special issue, the seawater effect on the impact damping behavior of the viscoelastic material of PTMD is reported for the first time [33]. It is found that the seawater has a minimal effect on the viscoelastic materials for their damping effectiveness.

This special issue also reports other types of new energy dissipation devices, such as a multi-unit particle damper [34], a nonlinear eddy current damper [35], and layered dampers [36,37]. Furthermore, also reported in this issue are structural elements with innovative designs to dissipate energy [38-40]. In addition, this special issue also reports two research studies on the dynamic responses of a structural foundation [41] and an earth-retaining structure [42]. Though most papers in this special issue are related to passive methods, one paper reports a semi-active vibration control via magnetorheological dampers (MRDs) [43], and another two papers report active vibration controls using piezoelectric transducers [44] and inertial actuators [45], respectively. MRDs are essentially passive devices, though their damping forces can be actively adjusted via electromagnets [20]. Please note that, for active vibration control, piezoelectric transducers have quick response and wide bandwidth [46-48], however, their outputs as displacement or force are limited. On the other hand, though most inertial actuators have low bandwidth, they can deliver much larger displacement or force for active vibration control. A special novel liquid transfer active balancing system to reduce oscillations of hollow rotors for high-speed rotating machinery is presented in this issue [49]. Finally, this special issue includes one review paper on the topic of seat suspension technology [50].

In summary, the topics in the special issue include new damping materials development [37], new damper vibration modeling, novel algorithms for active vibration control [44,45], novel passive damping methods and devices [25-30], innovative energy dissipation devices [38-40], and an explorative characterization of materials for energy dissipation [33], among others. For the future trends of research in energy dissipation for vibration control, two avenues should be noted. One avenue points to the integrated vibration control and energy harvesting. Piezoelectric transducers [51,52] and electromagnetic devices [53] can be used to convert vibration energy into electrical energy, reducing structural vibration while harvesting energy. The success of energy harvesting from structural vibration will lead to the second avenue for future work which is the integrated structural vibration control and health monitoring. The harvested energy that dissipates structural vibration can 
be used to power sensors that are used in structural health monitoring (SHM) systems. Though many advances have been made in SHM [54,55], the limited power source is currently a major roadblock for the wide application of SHM systems [56]. It is believed that integrated structural vibration control and health monitoring with energy harvesting is an effective way to promote future SHM systems.

Conflicts of Interest: The authors declare no conflict of interest.

\section{References}

1. Ho, M.; El-Borgi, S.; Patil, D.; Song, G. Inspection and monitoring systems subsea pipelines: A review paper. Struct. Health Monit. 2019. [CrossRef]

2. Jiang, J.; Zhang, P.; Patil, D.; Li, H.N.; Song, G. Experimental studies on the effectiveness and robustness of a pounding tuned mass damper for vibration suppression of a submerged cylindrical pipe. Struct. Control Health Monit. 2017, 24, e2027. [CrossRef]

3. Davis, L.; Hyland, D.; Yen, G.; Das, A. Adaptive neural control for space structure vibration suppression. Smart Mater. Struct. 1999, 8, 753. [CrossRef]

4. Meyer, J.L.; Harrington, W.B.; Agrawal, B.N.; Song, G. Vibration suppression of a spacecraft flexible appendage using smart material. Smart Mater. Struct. 1998, 7, 95. [CrossRef]

5. Lepine, J.; Rouillard, V. Evaluation of Shock Detection Algorithm for Road Vehicle Vibration Analysis. Vibration 2018, 1, 16. [CrossRef]

6. Li, H.N.; Yi, T.H.; Ren, L.; Li, D.S.; Huo, L.S. Reviews on innovations and applications in structural health monitoring for infrastructures. Struct. Monit. Maint. 2014, 1, 1-45. [CrossRef]

7. Mršnik, M.; Slavič, J.; Boltežar, M. Vibration fatigue using modal decomposition. Mech. Syst. Signal Process. 2018, 98, 548-556. [CrossRef]

8. Li, N.; Wang, F.; Song, G. New entropy-based vibro-acoustic modulation method for metal fatigue crack detection: An exploratory study. Measurement 2020, 150, 107075. [CrossRef]

9. Mirzabozorg, H.; Ghaemian, M.; Roohezamin, A. The reason of cracking in bottom gallery of SefidRud Buttress Dam and earthquake and post earthquake performance. Struct. Monit. Maint. 2019, 6, 103-124.

10. Li, L.; Song, G.; Ou, J. Hybrid active mass damper (AMD) vibration suppression of nonlinear high-rise structure using fuzzy logic control algorithm under earthquake excitations. Struct. Control Health Monit. 2011, 18, 698-709. [CrossRef]

11. Grammatikos, S.A.; Jones, R.G.; Evernden, M.; Correia, J.R. Thermal cycling effects on the durability of a pultruded GFRP material for off-shore civil engineering structures. Compos. Struct. 2016, 153, 297-310. [CrossRef]

12. Huo, L.; Li, C.; Jiang, T.; Li, H.N. Feasibility study of steel bar corrosion monitoring using a piezoceramic transducer enabled time reversal method. Appl. Sci. 2018, 8, 2304. [CrossRef]

13. Kong, Q.; Robert, R.; Silva, P.; Mo, Y. Cyclic crack monitoring of a reinforced concrete column under simulated pseudo-dynamic loading using piezo-based smart aggregates. Appl. Sci. 2016, 6, 341. [CrossRef]

14. Peng, J.; Xiao, L.; Zhang, J.; Cai, C.S.; Wang, L. Flexural behavior of corroded HPS beams. Eng. Struct. 2019, 195, 274-287. [CrossRef]

15. Zhang, $\mathrm{C}$; $\mathrm{Ou}, \mathrm{J}$. Control structure interaction of electromagnetic mass damper system for structural vibration control. J. Eng. Mech. 2008, 134, 428-437. [CrossRef]

16. Sethi, V.; Song, G. Optimal vibration control of a model frame structure using piezoceramic sensors and actuators. Modal Anal. 2005, 11, 671-684. [CrossRef]

17. Wang, W.; Hua, X.; Wang, X.; Chen, Z.; Song, G. Numerical modeling and experimental study on a novel pounding tuned mass damper. J. Vib. Control 2018, 24, 4023-4036. [CrossRef]

18. Yin, X.; Song, G.; Liu, Y. Vibration suppression of wind/traffic/bridge coupled system using multiple pounding tuned mass dampers (MPTMD). Sensors 2019, 19, 1133. [CrossRef]

19. Wang, W.; Hua, X.; Wang, X.; Wu, J.; Sun, H.; Song, G. Mechanical behavior of magnetorheological dampers after long-term operation in a cable vibration control system. Strut. Control Health Monit. 2019, 26, e2280. [CrossRef]

20. Liu, M.; Song, G.; Li, H. Non-model-based semi-active vibration suppression of stay cables using magneto-rheological fluid dampers. Smart Mater. Struct. 2007, 16, 1447. [CrossRef] 
21. Nagashima, I.; Maseki, R.; Asami, Y.; Hirai, J.; Abiru, H. Performance of hybrid mass damper system applied to a 36-storey high-rise building. Earthq. Eng. Strut. Dyn. 2001, 30, 1615-1637. [CrossRef]

22. Wang, W.; Hua, X.; Chen, Z.; Wang, X.; Song, G. Modeling, simulation, and validation of a pendulum-pounding tuned mass damper for vibration control. Strut. Control Health Monit. 2019, 26, e2326. [CrossRef]

23. Yan, B.; Ma, H.; Zhang, L.; Zheng, W.; Wang, K.; Wu, C. A bistable vibration isolator with nonlinear electromagnetic shunt damping. Mech. Syst. Signal Process. 2020, 136, 106504. [CrossRef]

24. Wang, W.; Wang, X.; Hua, X.; Song, G.; Chen, Z. Vibration control of vortex-induced vibrations of a bridge deck by a single-side pounding tuned mass damper. Eng. Struct. 2018, 173, 61-75. [CrossRef]

25. Li, L.; Liang, Q.; Qin, H. Equivalent Linearization Methods for a Control System with Clutching Inerter Damper. Appl. Sci. 2019, 9, 688. [CrossRef]

26. Zhang, C.; Wang, H. Swing Vibration Control of Suspended Structure Using Active Rotary Inertia Driver System: Parametric Analysis and Experimental Verification. Appl. Sci. 2019, 9, 3144. [CrossRef]

27. Wang, Z.; Yue, F.; Wang, H.; Gao, H.; Fan, B. Refined Study on Free Vibration of a Cable with an Inertial Mass Damper. Appl. Sci. 2019, 9, 2271. [CrossRef]

28. Xue, Q.; Zhang, J.; He, J.; Zhang, C. Control performance and robustness of pounding tuned mass damper for vibration reduction in SDOF structure. Shock Vib. 2016, 2016, 8021690. [CrossRef]

29. Song, G.B.; Zhang, P.; Li, L.Y.; Singla, M.; Patil, D.; Li, H.N.; Mo, Y.L. Vibration control of a pipeline structure using pounding tuned mass damper. J. Eng. Mech. 2016, 142, 04016031. [CrossRef]

30. Li, L.; Song, G.; Singla, M.; Mo, Y.L. Vibration control of a traffic signal pole using a PTMD with viscoelastic materials (II): Experimental verification. J. Vib. Control 2015, 21, 670-675. [CrossRef]

31. Tan, J.; Jiang, J.; Liu, M.; Feng, Q.; Zhang, P.; Ho, S.C.M. Implementation of Shape Memory Alloy Sponge as Energy Dissipating Material on Pounding Tuned Mass Damper: An Experimental Investigation. Appl. Sci. 2019, 9, 1079. [CrossRef]

32. Tan, J.; Ho, M.; Chun, S.; Zhang, P.; Jiang, J. Experimental Study on Vibration Control of Suspended Piping System by Single-Sided Pounding Tuned Mass Damper. Appl. Sci. 2019, 9, 285. [CrossRef]

33. Zhang, P.; Patil, D.; Ho, S.C.M. Effect of Seawater Exposure on Impact Damping Behavior of Viscoelastic Material of Pounding Tuned Mass Damper (PTMD). Appl. Sci. 2019, 9, 632. [CrossRef]

34. Ye, H.; Wang, Y.; Liu, B.; Jiang, X. Experimental Study on the Damping Effect of Multi-Unit Particle Dampers Applied to Bracket Structure. Appl. Sci. 2019, 9, 2912. [CrossRef]

35. Liang, L.; Feng, Z.; Chen, Z. Seismic Control of SDOF Systems with Nonlinear Eddy Current Dampers. Appl. Sci. 2019, 9, 3427. [CrossRef]

36. Zhai, J.; Li, J.; Wei, D.; Gao, P.; Yan, Y.; Han, Q. Vibration Control of an Aero Pipeline System with Active Constraint Layer Damping Treatment. Appl. Sci. 2019, 9, 2094. [CrossRef]

37. Ehrig, T.; Holeczek, K.; Modler, N.; Kostka, P. Dynamic Behaviour Adaptation of Lightweight Structures by Compressible Constrained Layer Damping with Embedded Polymeric Foams and Nonwovens. Appl. Sci. 2019, 9, 3490. [CrossRef]

38. Yin, Z.; Huang, Z.; Zhang, H.; Feng, D. Experimental Study on Energy Dissipation Performance and Failure Mode of Web-Connected Replaceable Energy Dissipation Link. Appl. Sci. 2019, 9, 3200. [CrossRef]

39. Yang, W.; Yan, R.; Suo, Y.; Zhang, G.; Huang, B. Experimental study on hysteretic behavior of the overlapped k-joints with concrete filled in chord. Appl. Sci. 2019, 9, 1456. [CrossRef]

40. Zhang, X.; Chen, Y.; Shen, X.; Zhu, Y. Behavior of circular CFST columns subjected to different lateral impact energy. Appl. Sci. 2019, 9, 1134. [CrossRef]

41. Bao, C.; Xu, F.; Chen, G.; Ma, X.; Mao, M.; Zhang, S. Seismic Vulnerability Analysis of Structure Subjected to Uneven Foundation Settlement. Appl. Sci. 2019, 9, 3507. [CrossRef]

42. Son, S.W.; Seo, M.; Im, J.C.; Yoo, J.W. Dynamic Numerical Analysis of Displacement Restraining Effect of Inclined Earth-Retaining Structure during Embankment Construction. Appl. Sci. 2019, 9, 2213. [CrossRef]

43. Fu, W.; Zhang, C.; Li, M.; Duan, C. Experimental Investigation on Semi-Active Control of Base Isolation System Using Magnetorheological Dampers for Concrete Frame Structure. Appl. Sci. 2019, 9, 3866. [CrossRef]

44. Peng, J.; Xiang, M.; Li, L.; Sun, H.; Wang, X. Time-Delayed Feedback Control of Piezoelectric Elastic Beams under Superharmonic and Subharmonic Excitations. Appl. Sci. 2019, 9, 1557. [CrossRef]

45. Ma, X.; Wang, L.; Xu, J. Active Vibration Control of Rib Stiffened Plate by Using Decentralized Velocity Feedback Controllers with Inertial Actuators. Appl. Sci. 2019, 9, 3188. [CrossRef] 
46. Wang, F.; Chen, Z.; Song, G. Monitoring of multi-bolt connection looseness using entropy-based active sensing and genetic algorithm-based least square support vector machine. Mech. Syst. Signal Process. 2020, 136, 106507. [CrossRef]

47. Liu, Y.; Zhang, M.; Yin, X.; Huang, Z.; Wang, L. Debonding Detection of Reinforced Concrete (RC) Beam with Near-Surface Mounted (NSM) Pre-stressed Carbon Fiber Reinforced Polymer (CFRP) Plates Using Embedded Piezoceramic Smart Aggregates (SAs). Appl. Sci. 2020, 10, 50. [CrossRef]

48. Wu, A.; He, S.; Ren, Y.; Wang, N.; Ho, S.C.M.; Song, G. Design of a new stress wave-based pulse position modulation (PPM) communication system with piezoceramic transducers. Sensors 2019, 19, 558. [CrossRef]

49. Pan, X.; Xie, Z.; Lu, J.; Wu, H.; Gao, J.; Jiang, Z. Novel Liquid Transfer Active Balancing System for Hollow Rotors of High-Speed Rotating Machinery. Appl. Sci. 2019, 9, 833. [CrossRef]

50. Heidarian, A.; Wang, X. Review on Seat Suspension System Technology Development. Appl. Sci. 2019, 9, 2834. [CrossRef]

51. Ma, Y.; Ji, Q.; Chen, S.; Song, G. An experimental study of ultra-low power wireless sensor-based autonomous energy harvesting system. J. Renew. Sustain. Energy 2017, 9, 054702. [CrossRef]

52. Ji, Q.; Ding, Z.; Wang, N.; Pan, M.; Song, G. A Novel Waveform Optimization Scheme for Piezoelectric Sensors Wire-Free Charging in the Tightly Insulated Environment. IEEE Internet Things J. 2018, 5, 1936-1946. [CrossRef]

53. Yan, B.; Yu, N.; Zhang, L.; Ma, H.; Wu, C.; Wang, K.; Zhou, S. Scavenging vibrational energy with a novel bistable electromagnetic energy harvester. Smart Mater. Struct. 2019. [CrossRef]

54. De Oliveira, M.; Monteiro, A.; Vieira Filho, J. A New Structural Health Monitoring Strategy Based on PZT Sensors and Convolutional Neural Network. Sensors 2018, 18, 2955. [CrossRef]

55. Huo, L.; Cheng, H.; Kong, Q.; Chen, X. Bond-slip monitoring of concrete structures using smart sensors-A review. Sensors 2019, 19, 1231. [CrossRef]

56. Ji, Q.; Parvasi, S.M.; Ho, S.C.M.; Franchek, M.; Song, G. Wireless energy harvesting using time reversal technique: An experimental study with numerical verification. J. Intell. Mater. Syst. Struct. 2017, 28, 2705-2716. [CrossRef] 